Author: Larisa ALEKSANYAN, Ph.D. (Political Science), Research Associate, Department of Political Science and Political Philosophy, Diplomatic Academy of the Ministry of Foreign Affairs of the Russian Federation (Moscow, Russian Federation)

Publication Date: 2021

Journal: Central Asia and the Caucasus. Vol. 22, Issue 4, pp. 59-70. DOI: 10.37178/ca-c.21.4.06

\title{
FOREIGN POLICY OF THE SOUTH CAUCASIAN COUNTRIES: RESULTS AND NEW CHALLENGES
}

\begin{abstract}
The newly independent states (South Caucasian countries being no exception), the products of the Soviet Union's traumatic disintegration, needed independent foreign policies. Throughout the three decades of their independence they formulated their priorities and defined approaches and principles under strong pressure of certain factors.

This process has been unfolding amid the complicated social and political processes and geopolitical transformations in the region shaken by the post-Soviet ethnic conflicts. As could be expected, the newly independent South Caucasian states opted for different routes in their economic and statehood development, while their ruling elites took into account the external and internal contexts when shaping their foreign policies.

Different approaches and different foreign policy priorities opened the doors to non-regional geopolitical actors: the United States, the European Union, Iran and Turkey have joined Russia, whose presence is rooted in its past. Recently, China, Israel and Japan have become interested in the region. Thus, today the regional countries are orientated to the interests of non-regional states. This has not benefited the situation in the region or cooperation among the regional states.

Foreign policy of the South Caucasian countries is inseparable from the regional security problems, which means that it should become an object of meticulous studies. In the latter half of 2020, the war in NagornoKarabakh changed the region's geopolitical setting and shattered its stability.

The article sums up the results of the policies pursued by the South Caucasian countries and identifies the challenges and possible developments in the region after the Karabakh war of 2020.
\end{abstract}

Keywords: Southern Caucasus, Armenia, Azerbaijan, Georgia, non-regional states. 


\section{Introduction}

Post-Soviet transfer was a complicated and even painful process for practically all former Soviet republics, $\stackrel{[11}{ }$ the South Caucasian states in particular. To promote their national interests, they needed independent foreign policy. However, this process was unfolding amid clashes of interests of regional and non-regional actors that sought to claim the leading roles in regional development.

Strategic relationships between the local states and global actors became one of the typical features of South Caucasian foreign policies: as small states, the regional countries opted for multi-vector and flexible foreign policy courses. .2$]$

The war in Nagorno-Karabakh and the complicated relations with Azerbaijan and Turkey led post-Soviet Armenia into a fairly convoluted social, economic and political situation. ${ }^{[3]}$

As an independent state, Armenia opted for complementarity, ${ }^{[4]}$ which presupposed partnership with all actors operating in the region. In this way Erevan demonstrated its openness to both friends and opponents. ${ }^{[5]}$ At the early stage of independence this approach allowed Levon Ter-Petrosian, the first president of Armenia, to pursue a successful foreign policy by meandering between Russia and the West, to develop relations with Islamic Iran and unstable Georgia and to negotiate diplomatic relations with Turkey. He never looked at Russia as an indispensable ally and was convinced that his country's stability and wellbeing could be promoted by closer relations with Turkey. ${ }^{[6]}$ Everything changed in 1993: Turkey closed the land border with Armenia to demonstrate its solidarity with Azerbaijan, Erevan responded with revised approaches to the country's security. ${ }^{[7]}$

“Azerbaijani and Turkish menace prompted Armenia's leadership to rethink its initial anti-Russian attitudes." $[81$ In 1995, the sides signed a treaty on a Russian military base in Armenia; in 1997, they signed a Treaty of Friendship, Cooperation and Mutual Assistance as the legal basis of their strategic cooperation. While developing its relations with Russia, Armenia spared no effort to rely on the West to the greatest possible extent to balance out its reliance on Russia in security matters. ${ }^{[9]}$

The economic situation in Azerbaijan, the Karabakh conflict and the pro-Russian sentiments in the country's political elite headed by Ayaz Mutallibov, the first president of Azerbaijan (1991-1992) made pro-Russian foreign policy practically inevitable. Changes began as soon as Mutallibov left his post. Abulfaz Elchibey, the second president of Azerbaijan, supported Pan-Turkism and an alliance with Turkey; the Karabakh conflict forced the Azeri leaders to look for allies among the regional and non-regional actors. Disappointed in the Communist ideology, people wanted a new development model for their country, which explains a very logical turn towards Turkey and the West. This, however, did not bring expected financial assistance from Turkey. In the 1990s, Heydar Aliyev, the third president of Azerbaijan, launched a more balanced foreign policy. He established constructive relations with the United States and Turkey and developed partnership with Russia, while avoiding military alliances and full-fledged regional economic integration with either side. $[10]$ 
Independent Georgia, likewise, shaped its foreign policy from scratch amid ethnic and political conflicts, a civil war and economic crisis, the complicated regional context and a highly negative attitude to the Soviet past.

At first, Georgia's foreign policy was determined by the conflicts in Abkhazia and South Ossetia and the anti-Russian sentiments of Zviad Gamsakhurdia, the first president of Georgia (1991-1992). Tbilisi broke off its relations with Russia ${ }^{[11]}$ for the sake of a closer relationship with the West in expectation of economic support, ${ }^{[12]}$ which never came. Under the pressure of Georgia's defeat in Abkhazia, an escalation of the civil war and economic collapse, the second president Eduard Shevardnadze readjusted his country's

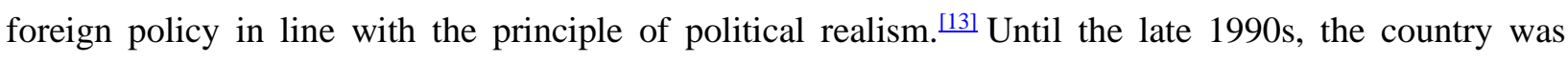
balancing between Russia and the West, it established useful contacts wherever possible; it did not abandon its pro-Western orientation ${ }^{[14]}$ and persisted in its multi-vector foreign policy course.

By the end of the 1990s, the South Caucasian states have generally managed to realize their multi-vector foreign policy course and continued balancing between global actors.

\section{Changes in the Foreign Policy of Armenia}

Robert Kocharian, the second president of Armenia (1998-2008) "heralded a new era of Armenian foreign policy, largely hailed as 'well-balanced'. He embarked on the construction of a new foreign policy identity that revolved around three core factors: genocide recognition; a complementary foreign policy; and, most importantly, full-scale European integration," ${ }^{[15]}$ with a peaceful settlement of the Karabakh conflict as its cornerstone.

Unlike his predecessor, ${ }^{[16]}$ he added the item of international recognition of Armenian genocide to his country's foreign policy agenda. At the same time, the Armenian leaders stated that recognition was a factor of moral rather than political importance, unrelated to the potential normalization of the Turkish-Armenian relations.

His ambitious agenda was based on "complementarity" and "involvement" (integration). ${ }^{[17]}$ Full-scale European integration became one of the foreign policy priorities. The first step in this direction was made in 2001, when Armenia joined the Council of Europe. ${ }^{[18]}$ Armenia's inclusion in the European Neighborhood Policy (ENP) (2005) was another important step in the same direction. Political and economic bilateral relations with European countries fostered Armenia's European integration course. $\frac{19]}{}$ Washington's increased interest in the region, which became apparent in the early 21 st century and the fairly big Armenian diaspora in the United States prompted Kocharian to turn his attention to the American dimension of his country's foreign policy. Erevan actively cooperated with the U.S. in the spheres of economy and defense, as well as anti-terrorist struggle and democratization; it took every chance to develop its contacts with NATO within the Partnership for Peace Program.

The relationship with Russia, however, have not disappeared from the agenda: "Kocharyan never questioned the significance of Armenian-Russian relations and viewed Russia as Armenia's indispensable 
and strategic partner, despite his overtures to the West." ${ }^{[20]}$ This moved Russia to the forefront in security and economic segments.

In 2002, Armenia became one of the founders of the CSTO, which consolidated the military and political relationship between Moscow and Erevan; it was further developed by the Inter-Governmental Agreement on Military-Technical Cooperation signed in 2003. ${ }^{[21]}$

In 2002-2008, Russia acquired access to the strategic assets of Armenia, the controlling blocks of shares in the energy giants - the Hrazdan Hydroelectric power Plant and the Metsamor Nuclear Power Plant - and three scientific research institutes. ${ }^{[22]}$ In 2006-2007, it acquired control over power networks, the biggest mobile operators and railways of Armenia and the Armenian part of the Iran-Armenia gas pipeline. Since 2005, Russia's investments in Armenia have been growing increasingly more impressive. ${ }^{[23]}$ By 2008 , the trade turnover between the two countries reached \$1,059 billion (19\% of Armenia's total trade turnover). [24] Armenia was expanding its relations with Georgia and Iran, the two transit countries that connected it with the rest of the world. Between 2001 and 2008, its trade turnover with Iran doubled, reaching \$228 million. ${ }^{[25]}$ Cooperation in electric power production was consolidated by the gas pipeline from Iran to Armenia, commissioned in 2007; the first and second Iran-Armenia high voltage transmission lines and an alternative $91-\mathrm{km}$ highway between the two countries were completed in the same year. ${ }^{[26]}$

Georgia's transit potential was very important for Armenia: the blockaded country received from 60 to $80 \%$ of its trade turnover from Georgian territory, ${ }^{[27]}$ traversed by part of the North-South main gas pipeline. Between 2001 and 2008, their trade turnover increased by 4.2 times. ${ }^{[28]}$ Increasingly more Armenians opted for the Georgian Black Sea resorts. ${ }^{[29]}$

Just as in the past, under Serzh Sargsian (2008-2018) Armenia paid particular attention to a peaceful settlement of the Karabakh conflict and international recognition of the genocide of Armenia. In 2008, in an effort to normalize bilateral relations with Turkey and open the borders, the Armenian leaders initiated a two-year "football diplomacy," which Ankara ignored.

Armenia has been growing more active in Europe: it hoped that it would change the South Caucasian political landscape to speed up its integration in European institutions through the EU Eastern Partnership Program (2009). Between 2010 and 2013, Armenia actively cooperated with the EU in a hope to sign the Association Agreement and become an Associate Member. However, in October 2013, during his visit to the Russian Federation, President Sargsian announced that Armenia would join the Customs Union and would contribute to the Eurasian Economic Union. Erevan was disappointed with the EU, which had done nothing to settle the conflict by peaceful means; the crisis in the RF-EU relationships was another negative factor. Armenia, however, continued developing its relationship with the EU; in 2017, it signed the Comprehensive and Enhanced Partnership Agreement (CEPA). ${ }^{[30]}$

Relations with the United States occupied an important place in Armenia's foreign policy ${ }^{[31]}$ due to the role Washington played in the peaceful settlement of the Karabakh conflict and the volume of humanitarian and technical assistance. Armenia also maintained its interaction with NATO.

Amid Armenia's developing relationships with non-regional actors, Russia remained its foreign policy priority. Erevan wanted deeper military, political and economic bilateral and multilateral cooperation. 
Armenia joined the Eurasian Economic Union in 2015. "The Armenian-Russian partnership is viewed as the most important and indispensable factor for the maintenance of stability and security in the South Caucasus." "[32] Five years earlier, in 2010, the sides had signed a protocol under which the Russian military base could remain in Armenia till 2044 to ensure the country's security together with the Armenian army. ${ }^{[33]}$ In 2013, the sides signed the Armenian-Russian treaty on the development of military and technical cooperation. In December 2016, Russia and Armenia created a regional air defense system and a united army group. "In 2016-2020 a total of 94\% of Armenian arms imports came from Russia."[34] Erevan paid a lot of attention to its relationship with Tbilisi in hopes of using Georgia's transit potential.

The countries' trade turnover continued to grow, increasing by 1.87 times; tourism, likewise, was developing.

Iran was and remains one of Armenia's foreign policy priorities. In 2008, the second part of the IranArmenia gas pipeline, a factor in Armenia's energy security, was completed. ${ }^{[35]}$ In 2017 , Armenia began creating the Meghri free economic zone to unite the markets of Iran, the EU, EAEU and China as an important factor in diversifying its blockaded economy. A temporary agreement signed between the EAEU and Iran aimed to create a free trade zone came into force in October 2019.

Today, in the context of its closer attention to the Southern Caucasus within the BRI initiative, China is moving to the fore in Armenia's foreign policy. It has already become one of its biggest trade and economic partners with a trade turnover of $\$ 393$ million in 2017. ${ }^{[36]}$

The velvet revolution of 2018 brought Nikol Pashinyan to power. The new leader focused on the domestic agenda, while confirming the previous foreign policy course — strategic cooperation with Russia. [37] "Other factors supporting the Russia's positive image in Armenia include the large Armenian Diaspora in Russia, estimated at approximately 2-2.5 million, and the importance of private remittances from Russia that, despite recent declines, still account for the majority of all remittances, with slightly over $\$ 1$ billion transferred to Armenia from Russia in 2019." "[38]

The results of the war in Nagorno-Karabakh, which began in September 2020, strongly affected Armenia's foreign policy. It lost control over a greater part of the unrecognized Nagorno-Karabakh Republic; when armed hostilities ended, Erevan was drawn into conflicts over the borders, and had to consolidate its sovereignty and security. Today, Karabakh settlement is its central foreign policy problem.

In the new geopolitical realities, military/political and military/technical cooperation with Russia is one of Armenia's priorities. Russia plays a huge role in modernizing and re-arming Armenia's armed forces; it is involved in protecting the Armenian-Azeri border. ${ }^{[39]}$ A balanced foreign policy has become a problem.

\section{Azerbaijan: Foreign Policy Evolution}

In the mid-1990s, Azerbaijan launched its multi-vector foreign policy based, to a great extent, on energy fuels. President Heydar Aliyev tried to use fuel export as a foreign policy instrument to consolidate his country's position in the Southern Caucasus, to settle the Karabakh conflict and develop the economy. The 
Azeri leaders established close relations with the West, which needed their energy resources. The West wanted access to the Caspian energy resources ${ }^{[40]}$ and a pipeline system that would bypass Russia and Iran. The Intergovernmental Agreement on the Construction of the Baku-Tbilisi-Ceyhan Oil Pipeline signed in 1999 and the Shah Deniz gas field, the biggest natural gas field in Azerbaijan discovered at approximately the same time, changed Baku's energy policy. ${ }^{[41]}$ Ties with the West were consolidated by the new energy export routes: from the late 1990s onwards Azerbaijan remains a member of TRACECA, the EU initiated transportation corridor Europe-the Caucasus-Asia. ${ }^{[42]}$

In his relationship with the West Heydar Aliyev tried, in particular, to somewhat diminish the roles of Moscow and the Armenian lobbies in the United States and Europe. ${ }^{[43]}$ In 1997, in an effort to balance out the global actors, Azerbaijan and Russia signed a Treaty on Friendship, Cooperation and Mutual Security, the legal foundation of bilateral relations, which made Russia one of the strategic partners and consolidated its trade and economic relations with Baku. ${ }^{[44]}$

Aliyev sought closer relations with the Muslim world and, in particular, a normalization of relations with Iran. During his visit to Tehran in 2002, the countries signed 10 documents on bilateral cooperation in customs control, transport, road building, communications and culture. ${ }^{[45]}$

In its relationship with Turkey, Azerbaijan relied, to a great extent, on their ethnocultural and religious closeness. In 1997, it developed into the "one nation-two states" formula of strategic political, economic and military importance.

In 2003, Ilham Aliyev came to power to continue his father's foreign policy course, which was based on the balancing and multi-vector principles. From 2003 on, he has been paying a lot of attention to his country's relationship with Russia, the EU and NATO, and Turkey, as well as the Karabakh conflict, ${ }^{[46]}$ while never letting the Western trend of foreign policy out of sight. ${ }^{[47]}$ In 2004, Azerbaijan joined the EU European Neighborhood Policy; in 2009, the Eastern Partnership program. The Baku-TbilisiCeyhan (2006), Baku-Tbilisi-Erzurum (2007) and the Southern Gas Corridor, the construction of which began in 2011, made Azerbaijan one of the most important EU partners in the energy sphere. ${ }^{[48]}$

In 2013, Aliyev refused to sign the association agreement with the EU; by that time his policy had become more balanced: the country was no longer ready to tie itself to any specific geopolitical bloc.

Ilham Aliyev's visit to the United States in 2006 revived the dialog between the two countries. ${ }^{[49]}$ In 2007 , Azerbaijan consolidated his country's military potential through the first Individual Partnership Action Plan with NATO. In 2011, cooperation between Azerbaijan and the U.S./NATO was somewhat subdued: by that time Baku had opted for a multi-vector foreign policy course. ${ }^{[50]}$ For the last decade, however, Azerbaijan has remained one of the members of NATO's Partnership for Peace initiative.

Baku's balanced foreign policy takes into account the Azeri diaspora in Russia; Aliyev remains convinced that his country needs to maintain military/technical and economic ties with Russia. In fact, the South Ossetia war of 2008, which changed the regional balance of forces, convinced the president of Azerbaijan that good relations with Moscow are a vitally important component of Karabakh settlement. $\frac{[51]}{\text { The }}$ Armenian-Russian allied strategic relationship is not an obstacle to successful military-technical cooperation between Baku and Moscow. In 2013, Baku acquired military equipment totaling \$4 billion 
from Russia. Escalation of the Karabakh conflict of 2016 did not strongly affect the two countries' bilateral relations. Strategic partnership in the military/technical, trade and economy spheres was maintained, amply confirmed by a 1.6-fold increase in trade turnover between 2008 and 2019. ${ }^{[52]}$ There are over $750 \mathrm{JVs}$ in Azerbaijan, 330 of them with $100 \%$ Russian capital. ${ }^{[53]}$ Bilateral cooperation in the humanitarian and cultural spheres is continuing.

In recent decades, the pro-Turkish vector has gained even more consequence in the Azerbaijani politics. ${ }^{[54]}$ Today Turkey plays a much bigger role than before in transportation of fuel resources from Azerbaijan to the world market. Moreover, their military/political partnership was expanded thanks to the Agreement on Strategic Partnership and Mutual Support signed in 2010 ${ }^{[55]}$ and the Declaration on the Strategic Cooperation Council, which invigorated the military/political, military/technical, humanitarian and economic relations between Baku and Ankara.

In September 2020, due to Turkey's large-scale military and diplomatic assistance, Azerbaijan began and won the war against the unrecognized Republic of Nagorno-Karabakh. The conflict remains unresolved, yet Turkey has consolidated its position in the region and its impact on Azerbaijan. In June 2021, Baku and Ankara signed the Shusha Declaration on the allied relationship, which raised their bilateral relations to a higher cooperation level. The document mainly deals with in the military and security spheres; the two countries are negotiating a joint Turkic army. ${ }^{[56]}$ Today, in the new geopolitical context, the pro-Turkic vector dominates Azerbaijan's foreign policy.

Georgia's role in the energy, transport and communication projects, in the East-West corridor and the much stronger Turkish-Azeri tandem convinced Baku that it needs a closer relationship with Tbilisi, first and foremost, in the economic sphere. Azerbaijan pours more money than any other country into Georgia, and is one of Georgia's biggest trade partners. Aliyev actively supports the tripartite format of TurkeyAzerbaijan-Georgia cooperation initiated by Ankara in 2012.

In the last decade, Azerbaijan has been demonstrating more interest in the Eastern trend of its foreign policy and in China, in the first place. The sides pay particular attention to the economy, transport and logistics, ${ }^{[57]}$ while Baku claims the role of a transport and communication corridor between China and Europe to diversify and upgrade its economy.

\section{Georgia's Foreign Policy Evolution}

In the mid-1990s, Eduard Shevardnadze performed a foreign policy U-turn towards the West. The 1999 Istanbul OSCE Summit accelerated the process: it was decided that Georgia would join the regional energy prospects. ${ }^{[58]}$ Encouraged by the new potentialities created by its cooperation with the West, and scared to a much greater extent than before by the "Russian threat" in the form of Moscow's support of Abkhazia and South Ossetia, Tbilisi was pushed closer to the West. ${ }^{[59]}$ In 2002 , Georgia expressed its desire to join NATO as one of its full-scale members. $\stackrel{[60]}{ }$ 
Under Shevardnadze, Euro-Atlantic and European integration became the key components of Georgian foreign policy; its relations with Turkey as a counterbalance to Russia's position in the region came to the fore and promoted Georgia's interests in the Euro-Atlantic structures.

The Rose Revolution of 2003, which brought Mikhail Saakashvili (2004-2013) to power, opened a new stage in Georgia's foreign policy. The country was moving farther away from Russia towards the West. Under Saakashvili, all official documents related to the foreign policy aims, tasks and strategic priorities reflected the country's pro-European course. Integration in NATO and the EU were two absolute foreign policy and national security priorities. ${ }^{[61]}$ In 2004, Georgia joined the EU European Neighborhood Program. In 2004, NATO approved the Individual Partnership Action Plan for Georgia, which launched wide-scale reforms of the country's defense system. In 2006, Georgia joined an active dialog on its NATO membership: "The Georgian government also sought to consolidate the bilateral military relationship, not least by contributing forces to alliance operations in Kosovo, and to the U.S. coalition in Iraq" and Afghanistan. Georgia spared no effort to consolidate bilateral military relations with the U.S. as well ${ }^{[62]}$ Saakashvili hoped that they would strengthen Georgia's security, help resolve internal conflicts and promote Euro-Atlantic integration.

The relationship with Russia was going from bad to worse. In 2006, Saakashvili signed the law, according to which the country withdrew from the Council of Defense Ministers of the CIS countries. The GeorgianRussian relations worsened after the Five-Day War of 2008, as a result of which Russia recognized the independence of South Ossetia and Abkhazia. The National Security Strategy of Georgia of 2011 defined Russia as an enemy and a threat to Georgia's national security. ${ }^{[63]}$

After the 2008 conflict, Georgia relied on its integration with the EU and NATO as a security guarantee. It was at the same time that the NATO-Georgia Commission was set up to promote Georgia's integration with the Alliance. In 2009, Tbilisi officially engaged in the first Annual National Program and joined the EU Eastern Partnership Program. In 2010, Georgian leaders began negotiations with the European Union on an association agreement with the EU.

Under Saakashvili, strategic cooperation with Turkey was treated as one of the foreign policy priorities. The relationship with Russia was worsening, while Turkey increased its influence in Georgia to the extent that it acquired certain military/political, economic and cultural instruments of its influence and further consolidated its position in Georgia. Saakashvili permitted Turkification of Ajaria, so to speak. Today, Turkey controls certain vitally important economic sectors in Georgia. ${ }^{[64]}$ In 2012 , the trade turnover between the two countries reached $\$ 1.6$ billion; Turkey imported commodities in the amount of $\$ 1.47$ billion. $\cdot[65]$

Georgia paid particular attention to its relations with Azerbaijan primarily because of the joint transportation and pipeline projects. After 2006, when the Russian Federation had discontinued gas supplies to Georgia, Azerbaijan increased its role in Georgia's foreign policy. Baku managed to replace practically all of the natural gas received by Georgia from Russia. Under Saakashvili, Azerbaijan with a trade turnover of $\$ 1.3$ billion in $2012^{[66]}$ became Georgia's second biggest trade partner after Turkey and one of the biggest investors. 
The relations between Georgia and Armenia remained good-neighborly: they are based on historical ties and Georgia's transit potential.

The victory of the opposition Georgian Dream Party at the October 2012 parliamentary elections opened a new stage in Georgia's foreign policy. "Integration in the European and Euro-Atlantic structures represents the main priority of the country's foreign policy course," while the U.S. remains the main ally. ${ }^{[67]}$ Georgia changed its attitude to Russia: today it is ready to abandon its anti-Russian rhetoric, settle the conflict and establish good-neighborly relations. The Government Program-For Strong, Democratic and Unified Georgia - says, in part, that one of the main objectives of Georgia's foreign policy is "de- escalating the existing tense relations with the Russian Federation and achieving the normalization of relations based on respect for Georgia's sovereignty, territorial integrity, inviolability of its internationally recognized borders." $" 68]$

The dialog Georgia initiated to normalize the relationship between the two countries revived bilateral relations with Russia in trade, economy, transportation and the cultural and humanitarian sphere. ${ }^{[69]}$ Russia annulled its embargo on Georgian import, simplified the visa regime for Georgians and restored transport communication with Georgia. Between 2012 and 2019, the trade turnover between Russia and Georgia increased 2.8-fold to reach the figure of $\$ 1.47$ billion. Georgian export rose nearly 10 -fold. ${ }^{[70]}$ The two countries, which disagreed on security issues, made trade the cornerstone of their cooperation. ${ }^{[711}$

Integration with NATO and the EU was and remains the two major goals of Georgian leaders. In 2014, Tbilisi signed an Association Agreement with the European Union. Enacted in 2016, it introduced a visafree regime for Georgian citizens and coordinated trade standards. ${ }^{[72]}$ No matter how hard Georgia tried to transfer its export flows from the CIS to the EU countries, in 2019 the share of the former in Georgia's export was $53.8 \%$ against $21.1 \%$ of the latter. ${ }^{[73]}$ In 2021 , Georgia announced that it intended to apply for a full-scale membership in the European Union in 2024.

It turned out rather difficult to become a member of NATO. "The Substantial NATO-Georgia Package (SNGP), a set of measures and initiatives aimed at strengthening Georgia's defense capabilities and developing closer security cooperation and interoperability with NATO Members" was approved in 2014. ${ }^{741}$ In 2020, the sides confirmed a revised SNGP, yet Georgia's future as a NATO and EU member remains vague and is highly improbable in the short term due to internal instability and territorial problems. In the last decade China acquired a special place and special consequence in Georgia's foreign policy. In 2017, the sides signed a free trade agreement; Georgia counts on considerable economic gains expected from the BRI project: Chinese investments $\frac{[75]}{}$ and economic diversification.

Georgia is not overjoyed by the region's new geopolitical context created by the Karabakh war and its results. It does not want Russia to have a greater role in the region; it does not need new transit corridors that will diminish its own role as a transit country, ${ }^{[76]}$ and is very cautious about Turkey's more powerful role in the region. To sum up: the altered balance of power in the Southern Caucasus; stronger Turkish influence and deepened Turkish-Azeri strategic alliance, on the one hand, and greater tension between Russia and the West, complicated relation between Washington and Tehran and confrontation between the U.S. and China, on the other, deprive Georgia of any chances to diversify its foreign policy contacts. 


\section{Conclusion}

Over the last decade, the foreign policies of all South Caucasian countries have depended, to a much great extent than before, on regional security. Their balanced and multi-vector foreign policy strategies have consolidated the positions of non-regional actors. In fact, in their foreign policies they were following the increasingly tense relationship between Russia and the West. Confrontation between these two global actors narrowed down the space for foreign policy maneuvers and made well-balanced policy practically impossible.

The second Karabakh war of 2020 and the altered balance of power in the region added new foreign policy challenges to the old ones. The new postwar geopolitical realities challenged Azerbaijan, which had, on the whole, successfully realized its "balancing policy" with the risk of stronger Euro-Atlantic (Turkish in particular) foreign policy component before the war. Armenia, which had relied on the balance of interests in its foreign policy in the past, had to master a new skill of meandering. Today, Georgia's pro-Western foreign policy and the vague prospects of its EU and NATO membership, the unregulated relations with Russia and potential new transport corridors demand a reassessment of its role in the region.

\section{References}

1. Kvarchelia, L. (2013). Instrumentalizatsia temy konflikta v politicheskom diskurse. Mify i konflikty na Iuzhnom Kavkaze, 2, International Alert, p. 14.

2. Degterev, D., Vasilyuk, I., \& Baum, V. (2018). Parametry mnogovektornosti vneshnej politiki stran SNG: prikladnoj analiz (Multiplexity Parameters of the CIS Foreign Policy: Applied Analysis). World Economy and International Relations, 62 (1), pp. 63-65.

3. Mikaelian, H. (2009). Armenian Foreign Policy: Coordinating the Interests of the U.S., the EU, and Russia. Central Asia and the Caucasus, No. 3 (57), 2009, pp. 116-124.

4. The term was put into circulation by Vartan Oskanian, Foreign Minister of Armenia in 1998.

5. Atoyan, V. (2015). Foreign Policy of Armenia: Politics Ensuring Maximal Security. Post-Soviet Issues, 3 (5), p. 99 (in Russian).

6. Ter-Petrosian, L. (2006). Selected Speeches, Articles, Interviews. Archives of the First President of Armenia, Erevan, p. 136 (in Armenian).

7. Manukian, J. (2014). Politika Turtsii na Iuzhnom Kavkaze i problemy bezopasnosti Respubliki Armenia 1991-2007gg. In: Vneshniaia politika respubliki Armenia. Problemy i vyzovy. Nauchnoprakticheskaia konferentsia, posviashchennaia 22-letiu nezavisimosti RA, 17 oktiabria 2013 goda, EGU, Erevan, p. 94.

8. Terzyan, A. (2018). Material Forces vs. the Force of Ideas: What Makes Russia Armenia's 'Best Friend'?. Armenian Journal of Political Science, 1 (8), p. 13. 
9. Minasian, S. (2013). Vneshniaia politika postsovetskoy Armenii: 20 let odnovremenno na neskolkikh stuliakh. Mirovaia ekonomika i mezhdunarodnye otnoshenia, No. 1, p. 85.

10. Shiriyev, Z. Azerbaijan's Relations with Russia: Closer by Default?. Russia and Eurasia Programme, Chatham House, March 2019, p. 4, available at [https://www.chathamhouse.org/sites/default/files/2019-03-14-Azerbaijan2.pdf], 1 June, 2021.

11. Bakhturidze, Z. (2015). Vneshniaia politika Gruzii 1991-2014 gg: kliuchevye orientiry i partnery. St. Petersburg, Avrora, p. 19.

12. Mikaelian, H., op. cit., p. 117.

13. Bakhturidze, Z., op. cit., pp. 25-26.

14. Bakhturidze, Z.Z. (2018). Vneshnepoliticheskiy kurs Gruzii v XXI veke: regionalnoe izmerenie. Publishing House of the Politechnical University, St. Petersburg, p. 30.

15. Terzyan, A. (2016). The Evolution of Armenia's Foreign Policy Identity: The Conception of Identity Driven Paths. Friends and Foes in Armenian Foreign Policy Discourse. The Role of Identity, Norms and Beliefs in Foreign Policy of Armenia and Georgia, p. 149.

16. L. Ter-Petrosian was convinced that "collective memory" of Armenian genocide of 1915 would negatively affect his country's foreign policy.

17. This means that the country should be involved in regional and world integration processes wellcoordinated with its domestic and foreign policy.

18. Council of Europe. Bilateral and Multilateral Relations. Ministry of Foreign Affairs of the Republic of Armenia, available at [https://www.mfa.am/en/international-organisations/5], 10 June, 2021.

19. Republic of Armenia. National Security Strategy, 2007, available at [https://www.mfa.am/filemanager/Statics/Doctrinerus.pdf], 10 June, 2021.

20. Terzyan, A. (2016). The Evolution of Armenia's Foreign Policy Identity: The Conception of Identity Driven Paths. Friends and Foes in Armenian Foreign Policy Discourse. The Role of Identity, Norms and Beliefs in Foreign Policy of Armenia and Georgia, p. 153.

21. Minasian, S. V kontekste problem regionalnoy bezopasnosti. Voenno-promyshlenny kuryer, No. 20 (87), 8 June, 2005, available at [https://vpk-news.ru/articles/1414\%20], 12 June, 2021.

22. Grigorian, G. (2017). Torgovo-ekonomicheskie otnoshenia mezhdu Armeniey i Rossiey (19912016). Rossia i novye gosudarstva Evrazii, 2, p. 57.

23. Statistical Yearbook of Armenia 2009. Statistical Committee of the Republic of Armenia, available in Russian at [https://armstat.am/ru/?nid=586\&year=2009], 1 July, 2021.

24. Ibidem.

25. Ibidem.

26. Iran. Bilateral Relations. Foreign Ministry of the Republic of Armenia, available at [https://www.mfa.am/hy/bilateral-relations/ir], 15 June, 2021.

27. Minasian, S. (2012). Armenia and Georgia: Problems and Prospects. Central Asia and the Caucasus, 13 (2), p. 47. 
28. Statistical Yearbooks of Armenia. Statistical Committee of the Republic of Armenia, available at [https://armstat.am/en/?nid=586], 1 June, 2021.

29. Minasian, S. (2012). Armenia and Georgia: Problems and Prospects. Central Asia and the Caucasus, 13 (2) pp. 46-47.

30. The Parliament of Armenia ratified this agreement on 11 April, 2018. In March 2021, it entered into force (see [https://ec.europa.eu/commission/presscorner/detail/en/IP_21_782], 21 June, 2021).

31. Annual Reports of the Foreign Ministry. Foreign Ministry of the Republic of Armenia, available at [https://www.mfa.am/hy/mfa-annual-report/], 21 June, 2021 (in Armenian).

32. Terzyan, A. (2016). The Evolution of Armenia's Foreign Policy Identity: The Conception of Identity Driven Paths. Friends and Foes in Armenian Foreign Policy Discourse. Values and Identity as Sources of Foreign Policy in Armenia and Georgia, p. 158.

33. Protocol No. 5 between the Russian Federation and the Republic of Armenia on changes in the treaty between the Russian Federation and the Republic of Armenia on the Russian military base in the territory of the Republic of Armenia of 16 March 1995, RF Foreign Ministry, available in Russian at [https://www.mid.ru/foreign_policy/international_contracts/2_contract/-/storageviewer/bilateral/page-

7/45120?_storageviewer_WAR_storageviewerportlet_advancedSearch=false\&_storageviewer_W AR_storageviewerportlet_keywords=\%D0\%B0\%D1\%80\%D0\%BC\%D0\%B5\%D0\%BD\%D0\%B 8\%D1\%8F\&_storageviewer_WAR_storageviewerportlet_fromPage=search\&_storageviewer_W AR_storageviewerportlet_andOperator=1], 18 June, 2021.

34. Wezeman, P., Kuimova, A., \& Wezeman, S. Trends in International Arms Transfers, 2020. SIPRI Fact Sheet, March 2021, p. 11, available at [https://www.sipri.org/sites/default/files/202103/fs_2103_at_2020_v2.pdf], 25 June, 2021.

35. Armenia and Iran exchange gas for electricity.

36. External Trade Database. Statistical Committee of the Republic of Armenia, available at [https://ec.europa.eu/commission/presscorner/detail/en/IP_21_782], 1 June, 2021.

37. Republic of Armenia. National Security Strategy, July 2020, available at [https://www.primeminister.am/u_files/file/Different/AA-Razmavarutyun-Final.pdf], 2 July, 2021 (in Armenian).

38. Poghosyan, B. (2020). Political and Economic Context of Armenian Membership in the Eurasian Economic Union. In: Armenia's Precarious Balance: The European Union (EU) and the Eurasian Economic Union (EAEU), Konrad Adenauer Stiftung, p. 17.

39. Aram Safarian: Armiano-rossiyskoe voenno-politicheskoe i voenno-tekhnicheskoe sotrudnichestvo nakhoditsia na samom vysokom urovne. Иносми.РУ, 9 July, 2021, available at [https://inosmi.ru/politic/20210709/250080882.html], 12 July, 2021.

40. Markova, E. (2021). US - Azerbaijan Relations in Caspian region (90s of the XX century). PostSoviet Issues, 8 (2), p. 289. DOI: 10.24975/2313-8920-2021-8-2-288-296 (In Russian). 
41. Zhiltsov, S. (2014). Energy Flows in Central Asia and the Caspian Region: New Opportunities and New Challenges. Central Asia and the Caucasus, 15 (4), p. 73.

42. Valiyev, A. (2017). Azerbaijan's foreign policy: What role for the West in the South Caucasus? Eastern Voices: Europes's East Faces an Unsettled West, Center for Transatlantic Relations, p. 139.

43. Markedonov, S. Rossia-Azerbaidzhan: protivorechivoe partnerstvo. RSMD, 1 November, 2013, available at [https://russiancouncil.ru/analytics-and-comments/analytics/rossiya-azerbaydzhanprotivorechivoe-partnerstvo/], 5 July, 2021.

44. Nasibova, A. (2019). Ot A. Mutalibova k G. Aliyevu: formirovanie vneshney politiki nezavisimogo Azerbaijana. Istoria. Mezhdunarodnye otnoshenia, 19 (1), p. 85.

45. Ibidem.

46. Avatkov, V. (2020). Osnovy vneshnepoliticheskogo kursa Azerbaidzhanskoy Respubliki na sovremennom etape. Kontury globalnykh transformatsiy, 13 (3), p. 126.

47. Azərbaycan Respublikasının milli təhlükəsizlik konsepsiyas1, 23 May, 2007 (National Security Conception of the Azerbaijan Republic, 23 May, 2007), available at [https://migration.gov.az/content/pdf/a959238a0eb184bcc3b26feb9c0cdec1.pdf], 5 July, 2021 (in Azeri).

48. Fedorovskaia, I. (2015). Azerbaidzhan i Evrosoiuz: zigzagi otnosheniy. Rossia i novye gosudartsva Evrazii, No. 1, p. 99.

49. Cornell, S. (2011). Azerbaijan since Independence. London, p. 412.

50. Areshev, A. (2014). Amerikano-Azerbaidzhanskoe sotrudnichestvo: 'Melkaia riab' i regionalny kontekst. Noev kovcheg, No. 17 (247), available at [https://noev-kovcheg.ru/mag/201417/4710.html], 27 June, 2021).

51. Aleksanyan, L. (2019). Gruzia vo vneshney politike Turtsii na sovremennom etape. $\mathrm{PhD}$ thesis, 23.00.04, Moscow, p. 24.

52. The Foreign Trade of Azerbaijan. The State Statistical Committee of the Republic of Azerbaijan, available at [https://www.stat.gov.az/source/trade/?lang=en], 5 July, 2021.

53. Kuklina, E. (2019). Energeticheskiy vektor rossiysko-azerbaidzhanskogo ekonomicheskogo sotrudnichestva v tsifrovom prostranstve sovremennogo mira. Eurasian Integration: Economics, Law, Politics, p. 54.

54. Nasibova, A. (2020). Stanovlenie i razvitie azerbaidzhano-turetskikh otnosheniy (1990-2010 gg.). $\mathrm{PhD}$ thesis, Saratov, p. 96.

55. Türkiye Cumhuriyeti ile Azerbaycan Cumhuriyeti arasında stratejik oratklık ve karşıllılı yardım anlaşması (Agreement on Strategic Partnership and Mutual Support between the Turkish Republic and the Azerbaijan Republic), available at [http://www.tbmm.gov.tr/sirasayi/donem23/yil01/ss645.pdf], 1 June, 2021 (in Turkish).

56. Turtsia i Azerbaidzhan reshili sozdat sovmestnuiu Tiurkskuiu armiu. RBK, 28 July, 2021, available at [https://www.rbc.ru/politics/28/07/2021/610111d89a794702833cd138], 1 July, 2021. 
57. Zhiltsov, S., Alexanian, L., Gavrilova, S., \& Markova, E. (2019). China in the Southern Caucasus. Central Asia and the Caucasus. English Edition, 20 (3), pp. 7-23.

58. Istanbul Document 1999-OSCE, Istanbul, 1999, p. 281, available at [https://www.osce.org/files/f/documents/6/5/39569.pdf], 12 July, 2021.

59. Ayvazian, A. (2020). Gruzia: vneshniaia politika malogo gosudarstva. Sovremennaia Evropa, 1, p. 87.

60. Leushkin, D., \& Sukhiashvili, D. (2019). Evoliutsia i osnovnye etapy otnosheniy Gruzii i NATO. Vestnik Nizhegorodskogo universiteta imeni N.I. Lobachevskogo, 1, p. 39.

61. National Security Concept of Georgia (2005), available in full at [https://mod.gov.ge/uploads/2018/pdf/NSC-ENG.pdf], 12 July, 2021; Foreign Policy Strategy 2006-2009, Foreign Ministry, available at [https://www.gfsis.org/media/download/GSAC/resources/115_1973_997704_Strategy_MFA2006 -2009En.pdf P. 9-10.], 12 July, 2021.

62. MacFarlane, N. (2013). The Reluctant Patron: Georgia-US relations. In: Georgian Foreign Policy: The Quest for Sustainable Security. Ed. by K. Kakachia and M. Cecire, Tbilisi. P. 88.

63. National Security Concept of Georgia, 2011, available at [https://mod.gov.ge/uploads/2018/pdf/NSC-ENG.pdf], 12 July, 2021.

64. Aleksanyan, L., op. cit., p. 96.

65. National Statistics Office of Georgia. External Trade, available at [https://www.geostat.ge/en/modules/categories/35/external-trade], 15 July, 2021.

66. Ibidem.

67. Resolution on Basic Directions of Georgia's Foreign Policy, 2013, available at [https://www.clingendael.org/sites/default/files/2016-02/Parlementsresolutie\%20Georgie.pdf], 15 July, 2021.

68. Government Program. Georgia, May 2015, available at [http://gov.ge/files/50258_50258_105367_15.07.17-May7,2015-

ForStrong,Democratic,andUnifiedGeorgia-GovernmentofGeorgiaProgram.pdf], 11 July, 2021.

69. Melikyan, J. (2014). Georgia's Foreign Policy After the October 2012 Parliamentary Elections. Central Asia and the Caucasus, 15 (1), p. 72.

70. National Statistics Office of Georgia. External Trade.

71. Karpovich, O., \& Shakirov, O. (2021). Russia and Georgia: Time to Interact. Post-Soviet Issues, 8 (1), p. 27 (in Russian).

72. Ayvasian, A., op. cit., p. 85.

73. National Statistics Office of Georgia. External Trade.

74. Relations with Georgia. NATO, available at [https://www.nato.int/cps/en/natohq/topics_38988.htm], 15 July, 2021.

75. Zhiltsov, S., Alexanian, L., Gavrilova, S., \& Markova, E., op. cit., p. 23. 
76. Priniali po-sosedski: Gruzia obnovila druzhbu s Armeniey i Azerbaidzhanom. Izvestia, 16 May, 2021, available at [https://iz.ru/1164283/kseniia-loginova/priniali-po-sosedski-gruziia-obnoviladruzhbu-s-armeniei-i-azerbaidzhanom], 16 May, 2021. 